\section{Mieczysław Celestyn Paczkowski OFM}

Uniwersytet Mikołaja Kopernika w Toruniu

celestyn@umk.pl

ORCID 0000-0002-4045-2314

DOI: http://dx.doi.org/10.12775/BPTh.2021.022

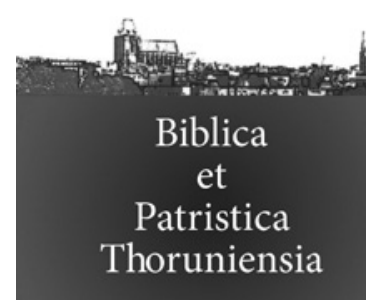

14 (2021) 4: 419-443

ISSN (print) 1689-5150

ISSN (online) 2450-7059

\title{
„Melior est canis vivus leone mortuo". Koh 9,4 w patrystyce greckiej i łacińskiej
}

\section{"Melior est canis vivus leone mortuo". Qo 9: 4 in Greek and Latin Patristics}

Streszczenie. Artykuł stanowi analizę interpretacji Koh 9,4 w tradycji chrześcijańskiej. $\mathrm{W}$ odniesieniu do egzegezy tego wersetu ma się do dyspozycji materiał o różnym charakterze. Poszczególne interpretacje pochodzą nie tylko z pism specyficznie egzegetycznych, ale także $\mathrm{z}$ dzieł o innym charakterze. Na tej podstawie można dostrzec kierunki interpretacji całej biblijnej Księgi Eklezjastesa, a także pojedynczego wersetu. $\mathrm{W}$ celu lepszego zrozumienia specyficznej tematyki, najpierw zostaje przedstawiona historia interpretacji Księgi Eklezjastesa w starożytności chrześcijańskiej. Koh 9,4 był wyjaśniany w sposób alegoryczny lub z odwołaniem się do prozopopei. Następnie zostały przeanalizowane znaczące fragmenty dzieł odnoszących się do Koh 9,4. Ojcowie Kościoła zajmowali się Koh 9,4 tylko okazyjnie, bowiem cała księga nie była zbytnio popularna wśród kaznodziejów i egzegetów epoki patrystycznej. Koh 9,4 był traktowany jako problem egzegetyczny do rozwiązania, jako przykład porzekadła, które otrzymało różne wersje i było używane także w kręgach kościelnych. Refleksja nad Koh 9,4 $\mathrm{w}$ okresie patrystycznym znajduje wiele punktów stycznych, ale także istnieją różnice w poszczególnych wyjaśnieniach tego wersetu. $\mathrm{W}$ ten sposób stworzono płaszczyznę dla jego bogatszej interpretacji już w epoce średniowiecza.

Abstract. The article discusses how Qo 9:4 was interpreted in the Christian tradition. Regarding the exegesis of Ecclesiastes, a different material is available. Various interpretations are derived not only from specifically exegetical literature but also from other kinds of works. On this basis, it is possible to observe the directions of the interpretation of this biblical book. To better understand the specific theme, it is necessary to analyze the history of the interpretation of this book in Christian antiquity when Qo 9:4 was interpreted in an allegorical manner or with the use of prosopopoeia. The attention is focused on the significant passages that report or evoke the verse in question. The Fathers treat Qo 9:4 only briefly, and in reality, Ecclesiastes was not greatly popular during the Patristic times. The passage was treated as an exegetical question to be resolved, an 
example of a proverb repeated in various environments, even the ecclesiastical one. The reflection on Qo 9:4 revealed numerous points of convergence as well as differences in the interpretation of this passage, thus establishing a platform for further interpretations of this text during the Middle Age.

Słowa kluczowe: Księga Eklezjastesa (Kohelet); Koh 9,4 (interpretacja); egzegeza patrystyczna; lew; pies.

Keywords: Book of Ecclesiastes (Qohelet); Qo 9: 4 (interpretation); patristic exegesis; lion; dog.

Koh 9,4 („Lepszy jest żywy pies niż zdechły lew”) to jedna $z$ wielu popularnych maksym, powtarzanych w formie porzekadła do dziś. Czy zdanie to było równie znane od początków przepowiadania wiary i literatury chrześcijańskiej? Odpowiedź nie jest łatwa. By ją znaleźć przyjrzymy się specyficzne mu wykorzystywaniu przez chrześcijan treści Księgi Koheleta. Werset Koh 9,4 odwołuje się do antytezy, w której zestawia się dwa dobrze znane zwierzęta: lwa i psa. Wzmianki o nich pojawiają się w księgach biblijnych, symbolice pogańskiej, żydowskiej i chrześcijańskiej. Wierni we wspólnotach, czytelnicy Biblii, pasterze wspólnot i pierwsi mnisi, choć rzadko, ale przywoływali Koheletową maksymę. Ograniczymy się wyłącznie do literatury greckiej i łacińskiej. Jednak Koh 9,4 pojawia się w różnych kontekstach: i nie tylko w systematycznych komentarzach biblijnych, ale również $\mathrm{w}$ listach, pouczeniach moralnych i w adresowanej do kręgów ascetycznych literaturze duchowej. Forma przysłowiowa Koh 9,4 stała się popularna w kręgach zachodnich dzięki tłumaczeniu Wulgaty.

\section{Kohelet w egzegezie moralno-duchowej Ojców Kościoła}

W NT nie ma cytatów wyjętych z Księgi Koheleta. Niektórzy dopatrują się jej echa w Rz 8,201 , chociaż kwestia jest dyskusyjna. Także Ojcowie Apostolscy nie

1 „Stworzenie bowiem zostało poddane marności - nie z własnej chęci, ale ze względu na Tego, który je poddał - w nadziei”. Interpretacja św. Augustyna brzmi następująco: „[Stworzenie oczekujące] objawienia synów Bożych to stworzenie, które teraz jest w człowieku i które będzie poddane marność i dopóki będzie oddawać się rzeczom doczesnym, przemijającym jak cień"; tenże, Expositio quarumdam propositionum ex Epistola ad Romanos LIII (ad Rom 8,19-23). 
interesowali się tą księgą biblijną. Faktem jest, że cytaty z Koh pojawiają się bardzo wcześnie (II w.), a komentarze do tej księgi biblijnej należą do najstarszych ${ }^{2}$. Księga Koheleta miała większe znaczenie w środowisku chrześcijańskim Aleksandrii niż w Antiochii ${ }^{3}$.

Nie brak więc dowodów bardzo wczesnego zainteresowania tekstem Eklezjastesa $^{4}$. Ten fakt wynikał $\mathrm{z}$ obecności w tym piśmie wątków bliskich nie tylko Żydom $^{5}$, ale także Grekom i chrześcijanom pochodzącym z tych kręgów ${ }^{6}$. Ponieważ u Koheleta doszukano się elementów epikureizmu i hedonizmu ${ }^{7}$, autorzy chrześcijańscy musieli zmierzyć się z tym wyzwaniem. Greccy czytelnicy odnajdywali u biblijnego mędrca także bliską im postawę dystansu i pogodzenia się z licznymi klęskami, najazdami barbarzyńców, kryzysami w sferze moralnej, społecznej i ekonomicznej. Echa refleksji nad tekstem Koheleta odnajduje się w aktach męczenników, a później w okresie rozwoju ascetyzmu monastycznego ${ }^{8}$. Ponadto swoje powodzenie Eklezjastes zawdzięczał domniemanemu autorstwu króla Salomo$\mathrm{na}^{9}$, który zredagował również inne księgi mądrościowe. Wyjaśnienie teologiczne triady ksiąg mądrościowych dał chociażby Hipolit Rzymski. Jego wyjaśnienie ma charakter trynitarny ${ }^{10}$. W tej wizji Kohelet to „księga Syna”, wcielonego Słowa ${ }^{11}$.

2 Wiadomo o niezachowanych Eklogach Melitona z Sardes, natomiast krótkiego streszczenia tej księgi biblijnej dokonał w Hypotyposeis Klemens Aleksandryjski. Zob. M. Starowieyski, Ksiega Eklezjastesa, s. 276.

3 Jeden z czołowych przedstawicieli egzegezy antiocheńskiej - Diodor z Tarsu napisał komentarz literalny do Koh. Dzieło to jednak zaginęło. Por. M. Starowieyski, Księga Eklezjastesa, s. 277-278.

4 Por. S. Leanza, I condizionamenti dell'esegesi patristica, s. 25-49. Dzieła wczesnochrześcijańskie poświęcone Księdze Eklezjastesa omawiają: M. Starowieyski, Księga Eklezjastesa, s. 270-305; K. Bardski, Poemat o czasie właściwym, s. 25-32 i M. Szram, „Wszystko ma swój czas", s. 347-348.

5 Zachował się Midrasz do Koh (Kohelet Rabbah), przypisywany rabbiemu Jehoszua z Siknin (III w. po Chr.).

6 Zob. M. Starowieyski, Księga Eklezjastesa, s. 271.

7 To przede wszystkim Koh 2,24-26; 3,12-13. 22; 5,17-19; 8,15; 9,7-10; 11,7-10.

8 Por. M. Starowieyski, Księga Eklezjastesa, s. 272.

9 Ciekawostką jest to, że Dydym Aleksandryjski nie był przekonany o Salomonowym autorstwie Koh. Zob. J. R. Wright, Ancient Christian Commentary on Scripture, t. 9, s. 192.

10 Ten schemat na ogół nie znalazł uznania wśród późniejszych autorów.

11 Por. Interpretatio Cantici Canticorum I 1-5. Por. S. Leanza, L'esegesi patristica di Qohelet, s. 239. 
Orygenes nadawał Biblii wyjątkowe znaczenie, stawiając ją na szczycie poznania ludzkiego. To właśnie on wpłynął na późniejszą egzegezę grecką i łacińską, wpisującą się w nurt zapoczątkowanej na przełomie II i III w. w środowisku aleksandryjskim interpretacji alegorycznej starotestamentowych tekstów. Aleksandryjczyk ${ }^{12}$ nawiązał do Salomonowego autorstwa Księgi Koheleta. Chociaż nie ma mowy w tej księdze o Salomonie, „lecz napisano: «Słowa Eklezjastesa, syna Dawida ${ }^{13}$, króla Izraela w Jerozolimie» (Koh 1,1)... [Tam] wymienia lud, ale też określa miejsce królowania - Jerozolimę ${ }^{\text {"14 }}$. W wyjaśnieniu imienia autora księgi Aleksandryjczyk wykorzystuje zbieżność określenia Eklezjastes (gr. „przemawiający na zgromadzeniu”) z nazwą Kościoła (gr. ekklesia) ${ }^{15}$.

Ponadto Eklezjastes, według słów Orygenesa, ,jest sługą woli Ducha Świętego" ${ }^{\text {". }}$. Ta księga uczy więc, że „to wszystko, co widzialne i cielesne, jest znikome i ułomne, a gdy człowiek zabiegający o mądrość zrozumie, że tak jest istotnie, niewątpliwie okaże wzgardę i lekceważenie tym sprawom, a wyrzekłszy się [...] całej doczesności dążyć będzie do tego, co niewidzialne i wieczne"17. W prologu do komentarza do Pnp Aleksandryjczyk połączył ze sobą trzy księgi Salomona (Przysłów, Koheleta i Pieśń nad pieśniami) ${ }^{18}$. Uważał, że te trzy księgi mądro-

12 Z komentarza Orygenesa zachowało się jednak bardzo niewiele Nieliczne fragmenty opracował S. Leanza. Zob. M. Simonetti, Między dosłownością a alegoria, s. 92, przyp. 97.

13 W starożytnych komentarzach zwracano uwagę, że jest to tytuł chrystologiczny. Por. M. Starowieyski, Księga Eklezjastesa, s. 273, przyp. 10.

14 Commnetarium in Canticum canticorum I, 6.

15 Por. S. Kalinkowski, w: Orygenes, Komentarz do „Pieśni nad Pieśniami”, s. 32, przyp. 151.

16 Commnetarium in Canticum canticorum I, 6.

17 Commnetarium in Canticum canticorum I, 4.

18 Podobnie w De principiis ukazuje, że Boża mądrość to nieskończone bogactwo. Dlatego Pismo Św. ma dla każdego odpowiedni „pokarm” zaspokajający jego potrzeby. „Z samego Pisma czerpiemy naukę, jak o nim należy myśleć. U Salomona w Księdze Przysłów znajdujemy taki nakaz odnoszący się do przestrzegania Pisma Świętego: «I ty, powiada, zapisz sobie potrójnie w pamięci i rozumie, abyś mógł prawdziwie odpowiadać tym, którzy cię pytać będą» (por. Prz 22,20.21). Potrójnie więc należy zapisywać w swej duszy wszelkie rozumienie pism Bożych: to znaczy żeby każdy prosty człowiek czerpał zbudowanie z samego [...] ciała Pisma - bo tak nazywamy pojmowanie zwyczajne i historyczne; jeśli zaś ktoś zaczął już czynić postępy i może patrzeć nieco szerzej, niech się buduje samą duszą Pisma; ci zaś, którzy są doskonali i podobni do tych, o których mówi Apostoł: «Głosimy mądrość między doskonałymi, ale nie mądrość tego świata ani mądrość władców tego świata, którzy giną, lecz głosimy mądrość Bożą ukrytą w tajemnicy, którą przed wiekami Bóg przeznaczył dla naszej chwały» (1 Kor 2, 6-7)", De principiis IV,2,4. 
ściowe obejmują całą ludzką wiedzę ${ }^{19}$, stanowiąc jednocześnie kolejne poziomy duchowego rozwoju człowieka ${ }^{20}$, które on stopniowo osiąga, przechodząc od rzeczy widzialnych i naturalnych do niewidzialnych i wiecznych ${ }^{21}$. Orygenes utożsamiał Koh z filozofią naturalną ${ }^{22}$. Powodem jest to, że natchniony autor w tej księdze „mówił wiele o problemach przyrodniczych [...], odróżniał przy tym sprawy próżne i marne od pożytecznych i potrzebnych" ${ }^{23}$. Trychotomia zastosowana w ujmowaniu znaczenia ksiąg mądrościowych była ważna, jeśli chodzi o ogólną wizję pism natchnionych.

Grzegorz Cudotwórca, uczeń i wielki zwolennik Orygenesa, pozostawił parafrazę Księgi Eklezjastesa. Swoje dzieło ukończył on prawdopodobnie krótko po powrocie do Neocezarei, gdzie został biskupem ${ }^{24}$. Charakterystyką tego dzieła było raczej swobodne potraktowanie tłumaczenia tekstu Septuaginty ${ }^{25}$. Autor starał się uwydatnić pouczenia moralne, a celem wyjaśnienia trudnych passusów używał prozopopei.

Komentarz do Koh autorstwa Dydyma Ślepego został odnaleziony wśród papirusów z Tura (1941 r.). Dzieło daje wgląd w egzegezę biblijną, teologię oraz praktykę edukacji i formacji. Wywód ma charakter akademicki, a sam komentarz koncentruje się na wyjaśnieniu trudności napotykanych przy lekturze tekstu oraz na pogłębieniu nauki moralnej przekazanej przez natchnionego autora. Wyjaśnienie miało charakter tropologiczny i obfitowało w wątki eklezjologiczne ${ }^{26}$.

Grzegorz z Nyssy w interpretacji Koh szedł po linii Orygenesa. Problem stanowiły dla niego wątki o charakterze „epikurejskim”. Dzięki alegoryzacji uda-

19 Pierwsza napisana została dla ludzi początkujących w rozwoju duchowym, druga dla postępujących i dojrzałych w cnotach, a trzecia dla doskonałych.

${ }^{20}$ Wielu autorów powieliło pomysł Orygenesa (Grzegorz z Nyssy, Ewagriusz, Hieronim i Teodoret).

21 Zob. S. Holm-Nielsen, On the Interpretation of Qoheleth, s. 175-176; M. Simonetti, Między dosłownością a alegorią, s. 92 przepis 97.

${ }^{22} \mathrm{~W}$ tradycji judaistycznej Eklezjastes to dzieło pochodzące z okresu dojrzałego życia natchnionego autora.

23 Commnetarium in Canticum canticorum I, 4.

24 Niektóre kodeksy błędnie przypisują autorstwo tej parafrazy Grzegorzowi z Nazjanzu.

25 Por. J. Quasten, Patrologia, t. 1, s. 390.

26 S. Leanza, Sapienziali (libri), NDPAC, t. 3, kol. 4735. N.B.: Hasła słownikowo-encyklopedyczne nie są cytowane w bibliografii. Znajdują się tam tylko odnośniki do całościowych publikacji tego typu. 
ło się te elementy zinterpretować w harmonii z moralnością chrześcijańską ${ }^{27}$. Dla Grzegorza ten starotestamentowy tekst mądrościowy nadawał się dobrze do ukazania marności świata i wszystkich jego dóbr. Taką zresztą interpretację przedstawiali inni starożytni egzegeci chrześcijańscy ${ }^{28}$.

W swoim komentarzu Grzegorz interpretuje pierwsze trzy rozdziały Księgi Koheleta. Konsekwentnie przenosi tekst z poziomu materialnego do duchowego $^{29}$. Inne problemy interpretacyjne Nysseńczyk rozwiązywał na bazie prozopopei: hipotetyczny rozmówca Eklezjastesa porusza pewne kontrowersyjne kwestie. Także sam król Salomon mógł powtarzać pewne obiegowe opinie, a później je wyjaśniać ${ }^{30}$. Księga ta wymagała szczególnego zaangażowania egzegety. Nysseńczyk uważał, że Eklezjastes to księga, „z której pożytek jest tak wielki, jak wiele trudu wymaga jej rozważanie" 31 . Postać autora Koh to w ujęciu Nysseńczyka zapowiedź Chrystusa ${ }^{32}$.

Komentarz do Eklezjastesa przypisywany Janowi Chryzostomowi został odnaleziony w bibliotece monastyru na wyspie Patmos (1890 r.). Autor utożsamiany ze Złotoustym ${ }^{33}$ prezentuje egzegezę o charakterze literackim, co jest typowe dla kręgu antiocheńskiego. Metodologia tego typu jest stosowana bez obawy, mimo, że czytelnicy z pewnością napotykali na trudności w zetknięciu się z przemyśleniami Koheleta. Analiza stylu i treści wskazuje, że autorem jego tego komentarza nie był biskup Konstantynopola: styl jest prosty, a egzegeza skromna i powierzchowna ${ }^{34}$. Porównanie tego dzieła $\mathrm{z}$ tekstami Jana Chryzostoma nawiązującymi do Koheleta lub cytującymi go, choć nie brak podobieństw, wykazują wyraźną rozbieżność. To, co autora komentarza zbliża do Jana Chryzostoma, to dystans wobec metody alegorycznej. Komentator uważał, iż Eklezjastes „mówi do świata o rzeczach zwykłych" ${ }^{35}$.

27 Nysseńczyk przyjął podział ksiąg mądrościowych (Prz, Koh i Pnp) wg koncepcji Orygenesa; por. J. Grillo, Is Patristic Exegesis Good for Biblical Scholarship?, s. 239-241.

28 Por. M. Simonetti, Między dosłownościa a alegorią, s. 152.

29 Por. przykład opisany w: M. Simonetti, Między dosłownością a alegorią, s. 153.

30 Por. S. Leanza, Sapienziali (libri), kol. 4736.

31 In Ecclesiasten I, 1.

32 Por. J. Grillo, Is Patristic Exegesis Good for Biblical Scholarship?, s. 237-239.

33 Nie wiadomo nic o jakimkolwiek komentarzu do Koheleta Jana Chryzostoma. Ponadto w katenach do tej księgi nie ma fragmentów z imieniem Złotoustego.

34 Zob. S. Leanza, Praefatio, w: Corpus Christianorum. Series Graeca 4, s. 55.

35 In Ecclesiasten I, 1. 
Ważne miejsce zajmuje interpretacja Hieronima, który zdobycze refleksji Orygesowskiej przekazał późniejszym epokom ${ }^{36}$. Jego komentarz do Eklezjastesa to jedno z najlepszych dzieł tego rodzaju, które ma podstawowe znaczenie dla historii egzegezy chrześcijańskiej. Przede wszystkim dlatego, że Dalmata starał się opierać na tekście oryginalnym, posługując się dostępnymi manuskryptami, głównie z biblioteki w Cezarei Nadmorskiej. Strydończykowi przyświecały cele apologetyczne: obrona natchnionego tekstu przed oskarżeniami o hedonizm i epikureizm. Jego komentarz jest oszczędny, i zachowuje równowagę pomiędzy interpretacją mistyczno-alegoryczną ${ }^{37}$, a refleksją bazującą na filologii, co było charakterystyczne dla metodologii autora Wulgaty.

Decydujący wpływ na egzegezę syryjską wywarł Teodor z Mopsuestii ${ }^{38}$. Jego komentarz do Koh w większej części opierał się na interpretacji dosłownej tekstu. Autor ten kwestionował charakter natchniony tej księgi mądrościowej. Tak więc zaprzeczał nie tylko natchnionemu charakterowi Pnp, ale sformułował tezę o ograniczoności natchnienia Eklezjastesa.

Swoje powodzenie Księga Koheleta zawdzięczała w zasadzie trzem egzegetom: Orygenesowi, Hieronimowi i Teodorowi z Mopsuestii. Ci pisarze stanowili raczej wyjątki, gdyż większość materiału egzegetycznego znajduje się w tzw. „katenach”. Prokopiusz z Gazy (przełomV i VI w.), najwybitniejszy twórca tej formy literackiej ${ }^{39}$, sięgał po fragmenty pism Orygenesa, Grzegorza Cudotwórcy, Dionizego Aleksandryjskiego, Dydyma, Ewagriusza z Pontu i Nila z Ancyry ${ }^{40}$. $\mathrm{Z}$ fragmentów komentarzy tych autorów można wnioskować, że egzegeza alegoryczna i moralna Koh była szeroko praktykowana. Wiele spostrzeżeń starożytnych egzegetów było dokonywanych na bazie egzegezy dosłownej, wspomaganej przez prozopopeję. Istnieją jednak przypadki, że pozostawała tylko interpretacja alegoryczna. Tym sugestiom w lekturze Koh warto się bliżej przyjrzeć.

36 Próbę czasu przetrwał komentarz Hieronima, do którego należy dodać dzieło Grzegorza z Agrigentum.

37 Dla Hieronima „alegoria” oznacza sens duchowy. Por. A. Penna, Principi e carattere dell'esegesi di S. Girolamo, s. 123.

38 Jego spuścizna literacka zachowała się tylko w niewielkiej części. Na ten temat por. J. Quasten, Patrologia, t. 2, s. 406-416. Tradycja Kościoła wschodniosyryjskiego okazała się bardzo bogata w materiał egzegetyczny z dzieł przetłumaczonych na język syryjski.

39 O. von Bardenhewer, Geschichte der altkirchlichen Literatur, t. 5, s. 86.

40 Wydanie Leanzy opatrzono komentarzem skrypturystycznym, patrystycznym i krytycznym. Por. M. Starowieyski, Księga Eklezjastesa, s. 282 i 294. 


\section{Alegoria czy prozopopeja?}

Z zachowanych fragmentów komentarzy, homilii, jak również na podstawie materiału zawartego w katenach można sobie wyrobić obraz metodologii egzegetycznej stosowanej w przypadku Księgi Eklezjastesa. Egzegeci pracowali według zasady, by we wszystkich wypowiedziach Pisma Świętego poszukiwać pożytku duchowego. Jeśli nie dało się go znaleźć w sensie dosłownym, odwoływano się do interpretacji alegorycznej. W przypadku Koh 9,4 najwyraźniej jednak nie wykorzystano potencjału symbolicznego zestawionych zwierząt: psa i lwa.

Na postrzeganie obu tych stworzeń kluczowe znaczenie miała Biblia. Dla autorów starożytnego Kościoła natchnione pisma były nie tylko najwyższym autorytetem w sferze doktryny i nauczania duchowego, ale również w kwestiach przyrodniczych. Biblia w wielu miejscach dystansuje się od pozytywnego obrazu psa. Może to trochę dziwić, bo przecież od najdawniejszych czasów psy towarzyszyły człowiekowi, zarówno na polowaniach, jak i stróże jego trzód, siedzib i własności. Ich przywiązanie, czujność i wierność sprawiły, że wśród starożytnych ludów dostrzegano w psach symbole tych właśnie cech, jak i stworzenia pomocne w określonych sferach ludzkiej aktywności. Jednak generalne przekonanie było takie, iż psy, ze względu na niektóre swoje zachowania i instynktowne odruchy, są stworzeniami godnymi pogardy. Odzwierciedla to Pismo Święte, mówiące najczęściej o psie w złym i pogardliwym znaczeniu (por. Ps 22,17.21; Prz 26,11) ${ }^{41}$. Używano tego określenia jako wyzwiska ${ }^{42}$ i widziano w tym zwierzęciu obraz ludzi bezbożnych, ogarniętych nienawiścią, żądnych krwi, niemoralnych ${ }^{43}$. Negatywnego obrazu psa w Biblii dopełnia uznanie go za zwierzę nieczyste, nawet jeśli nie występuje w spisie takowych gatunków w Kpł 11 i Pwt $14^{44}$. Słowa Chrystusa: „Nie dawajcie psom tego, co święte” (Mt 7,6) nie

41 Ten ostatni fragment przywołuje 2 P 2,22. Por. U. Schattner-Rieser, Le „Chien”, s. 295.

42 Istniało wiele obelg, które zawierały motyw. Zob. J. Lemański, Negatywny obraz psa $w$ Biblii, s. 68-76.

43 Obrazowo to ci, którzy nie mogą wejść do królestwa Bożego: „Na zewnątrz są psy, guślarze, rozpustnicy, zabójcy, bałwochwalcy i każdy, kto kłamstwo kocha i nim żyje” (Ap 22,15).

44 Por. U. Schattner-Rieser, Le „Chien”, s. 294. 
sugerowały pozytywnych skojarzeń. Wyjątek stanowi Księga Tobiasza ${ }^{45}$ oraz Job $30,1^{46}$. W literaturze apokryficznej pojawia się motyw psów reprezentujących wrogie wobec Izraela siły (por. 1 Hen 89,10-11.42), przede wszystkim Filistynów (zob. 1 Hen 89,47) ${ }^{47}$.

W starożytnej myśli chrześcijańskiej pies posiadał symbolikę ambiwalentną. Egzegeza chrześcijańska nawiązywała do negatywnego znaczenia określenia „pies”, jeśli wynikało ono z tekstu Pisma Świętego. U św. Augustyna ${ }^{48}$ „pies” oznacza heretyków, którzy winni zostać wyrzuceni poza bramy miasta-Kościoła ${ }^{49}$. W źródłach monastycznych jest wzmianka o tych członkach wspólnot, których porównuje do psów. Konotacje tego porównania były negatywne ${ }^{50}$.

Pozytywne cechy psa uwydatniano w homiletyce epoki patrystycznej. Bazyli Wielki był przekonany, że psy dzięki szczególnie wyostrzonym zmysłom, mogą być uważane za zwierzęta inteligentne ${ }^{51}$. Kapadocczyk wychwala takie cechy psów, jak wdzięczność okazywana właścicielowi, wierność oraz zdolność do zdemaskowania morderców swoich panów. Nie brak także nauczenie moralnego, bowiem kaznodzieja przestrzegał słuchaczy, by okazywali wdzięczność Stwórcy i nie obdarzali przyjaźnią niegodziwców ${ }^{52}$.

W podobnym tonie wyraża się Ambroży, który również wskazywał na wdzięczność tych zwierząt i czujność w pilnowaniu pana ${ }^{53}$. Stąd zachęta, by także wierni, a przede wszystkim kierujący wspólnotami podnosili głos (jak

45 W tłumaczeniu Wulgaty (Tb 11,4) jest mowa o radosnym biegu psa, machaniu ogonem na znak radości ze szczęśliwego powrotu. Por. J. Lemański, Negatywny obraz psa w Biblii, s. 61, n. 66 .

46 Podobnie pies jest reprezentowany w Łk 16,21.

47 Por. U. Schattner-Rieser, Le „Chien”, s. 300.

48 Augustyn zwracał uwagę na niektóre elementy krytyki tekstu, co potwierdza fragment poświęcony Eklezjastesowi w Speculum (Liber de divinis scripturis).

49 Por. Enarrationes in Ps. 150, 16. Psy godne pochwały to te, które czuwają i szczekają w obronie swojego pana, por. ibidem, 67,32 .

50 Chodzi o mnichów, „którzy żyją we wspólnocie, ale mają własne dobra”. Powód jest następujący: „Pies nie pozostawia tego, co znalazł [...]. Nie ma rzeczy, od której by się nie powstrzymał", III Regula Pachomii, Apoftegmaty, t. 3, s. 66.

51 Por. In Hexaemeron IX, 4; 8.

52 Por. ibidem, IX, 10-11:

53 In Exaemeron (dies VI), Sermo IX, 4, 10-17. Mediolańczyk poszedł śladem refleksji Bazylego Wielkiego. 
szczekające psy), by bronić wiary ${ }^{54}$. Biskup Mediolanu uległ także chęci opowiedzenia wzruszającej historii psa, który boleje nad śmiercią pana, a potem rzuca się na jego zabójcę ${ }^{55}$.

W interpretacji Koh 9,4 pojawia się fragment Mt 15,26. Wyjaśnienie można znaleźć w komentarzu do pierwszej Ewangelii Hilarego z Poitiers. Wyjaśniał on, że „w związku z przywilejami [Izraelitów] lud pogański otrzymał określenie «psów». Jednak Kananejka, już zbawiona przez wiarę i pewna głębokich tajemnic, odpowiada, że także «szczenięta», a to przez to czułe zdrobnienie, uczyniła słodszym obraźliwa nazwę psów, «jedzą ze stołów ich panów»"56. Inny komentator dodawał, że „Żydzi zostali nazwani «dziećmi», podczas gdy «psami» nazywał [Chrystus] z pogan [...]. [To dlatego], że czczą bożków i podnoszą głos przeciw Bogu [...]. Tak oto poprzez wiarę poganie $\mathrm{z}$ «psów» stali się synami»"57.

Obraz lwa był przywoływany w kontekście siły, odwagi i majestatu. W sferze symboliki chrześcijańskiej ważną rolę odgrywał fakt, że w Starym Testamencie często porównywano to majestatyczne zwierzę do Mesjasza (por. Rdz 49,9-10) ${ }^{58}$, co znajduje swój wyraz w Ap 5,5: „Oto zwyciężył Lew z pokolenia Judy”.

Pochodzące z Fizjolog $a^{59}$, informacje o tym, że potomstwo lwa rodzi się ślepe i martwe, a dopiero po trzech dniach, ojciec rykiem i oddechem przywraca je do życia, stanowiły alegorię zmartwychwstania Zbawcy ${ }^{60}$. Podobnie interpretowane

54 „A co powiem o psach, w których naturze leży okazywanie wdzięczności pilnej czujności dla dobra swych panów? Stąd do tych, którzy zapominają o doznanych dobrodziejstwach i są leniwi i gnuśni, Pismo woła: «Psy nieme, szczekać nie mogące». A więc są psy, które potrafią szczekać w obronie swych panów, umieją bronić swe domostwa. A więc i ty naucz się podnosić głos w obronie Chrystusa, gdy na owczarnię Chrystusową napadają groźne wilki", In Exaemeron (dies VI), Sermo IX, 4, 17.

55 Ibidem, 4, 24.

56 Commentarius in Matthaeum XV, 4.

57 Epifaniusz Latinus, Interpretatio Evangeliorum 58. Komentarz Jana Chryzostoma dodaje, że „Kananejka została nazwana «szczenięciem», ale dodała, jak się one zachowują”, Jan Chryzostom, Homiliae in Matthaeum 52, 2.

58 „Judo, młody lwie, na zdobyczy róść będziesz mój synu”. W Chrystusie spełniło się to prorocze błogosławieństwo Jakuba.

59 Dosł. „Przyrodnik”. Dzieło powstało na przełomie II-IV w. Łączy elementy helleńskie i orientalne z chrześcijańskimi. Por. J. Łanowski, Physiologos, w: Słownik pisarzy antycznych, s. 363. Dzieło to oddziaływało silnie na tradycję literacką i ikonograficzną chrześcijaństwa za sprawą motywów oraz metody alegorycznej interpretacji świata natury.

60 Ambroży w komentarzu do Rdz 49,9 porównuje zbudzonego po odpoczynku lwa do zmartwychwstałego Chrystusa: „Widzę go martwym z Jego własnej woli, widzę śpiącym na 
były opisy, że lew śpi z otwartymi oczyma, a gdziekolwiek idzie, zaciera swoje ślady ogonem. Ten ostatni szczegół dotyczył narodzin Chrystusa, który chcąc zbawić ludzkość i zmylić szatana, narodził się z łona Dziewicy Maryi ${ }^{61}$.

Nawiązania do lwa miały charakter przede wszystkim chrystologiczny ${ }^{62}$, choć nie należy zapominać o dualizmie symbolicznym tego zwierzęcia ${ }^{63}$. Przedstawienia zarówno Samsona rozdzierającego paszczę lwa, jak i Daniela wychodzącego bez szwanku spośród tych zwierzą ${ }^{64}$, interpretowano się jako symbol zwycięstwa nad złem i śmiercią ${ }^{65}$. Wśród rad udzielanych ascetom nie brak takich, które odwołują się do wyobrażeń o lwie ${ }^{66}$.

W piśmiennictwie monastycznym nie tylko formułowano apoftegmaty, ale także stosowano metafory i przysłowia ${ }^{67}$. Dzięki swoim właściwościom, przysłowia mogły być używane w różnych sytuacjach ${ }^{68}$.W literaturze ascetycznej ma się wręcz wrażenie, że przywoływano mądrość ludową czy korzystano z porzekadeł obecnych w Biblii. Koh także podlegał tym procesom.

W przypadku pojawienia się trudności interpretacyjnych odwoływano się do prozopopei, czyli zasady rozróżniania lub zmiany mówiącej osoby. Tego ro-

własne życzenie. Czyż ten, który czyni wszystko własną mocą, będzie potrzebował pomocy kogoś innego, aby zmartwychwstać? Sam więc jest sprawcą swego zmartwychwstania, bo On jest Panem śmierci; na Niego czekają narody", De benedictionibus patriarcharum IV, 20, por. D. Forstner, Świat symboliki chrześsijańskiej, s. 278.

${ }^{61}$ Por. S. Kobielus, Bestiarium chrześcijańskie, s. 184; B. Purc-Stępniak, Lwy zła - lwy cnoty, s. 7.

${ }^{62}$ Lew symbolizował również ewangelistę Marka, którego Ewangelia rozpoczyna się od przepowiadania Jana Chrzciciela na pustyni, utożsamianej z miejscem przebywania lwów.

63 Por. M. Pastoureau, Średniowieczna gra symboli, s. 55-68.

${ }^{64}$ W literaturze chrześcijańskiej nie brakowało motywu świętych, którzy nie byli atakowani przez te drapieżniki. Tak jest w tradycji apokryficznej (Dzieje Pawła i Tekli), w opowiadaniach o męczennikach oraz w literaturze monastycznej (np. Vita Pauli autorstwa św. Hieronima).

${ }^{65}$ Por. przede wszystkim S. Kobielus, Bestiarium chrzésijańskie, s. 182.

${ }^{66}$ Mnich Hyperchios mówił między innymi, że, ,jak lew wzbudza lęk dzikich osłów, tak mnich pozostaje niewzruszony wobec myśli pełnych pożądliwości", Apophthegmata Patrum [kolekcja systematyczna] 66 (918) Ten sam apoftegmat znajduje się w kolekcji systematycznej greckiej (IV, 53).

67 Zwane także: aforyzmami, apoftegmatami, gnomami, sentencjami, czy „złotymi myślami”, por. D. Masłowska, W. Masłowski, Przystowia polskie i obce od A do Z, s. 22.

${ }^{68}$ W literaturze ludowej powiedzenia i przysłowia mają utrwaloną i powtarzaną formę wypowiedzi. Por. P. Müldner-Nieckowski, Wielki stownik frazeologiczny języka polskiego, s. 16. 
dzaju metody były dobrze znane egzegetom chrześcijańskim i należały do kanonów egzegetycznych, sięgających Arystarcha. Stosowano je w interpretacji dzieł Homera i Platona. Ten typ egzegezy tekstów natchnionych w pewnym stopniu został przygotowany przez Filona Aleksandryjskiego, prekursora również w tej dziedzinie. Wskazał on na podstawy biblijne tej metody, którą przejęli egzegeci chrześcijańscy jako wygodny sposób na zwracanie uwagi na specyficzne niuanse literackie i teologiczne niektórych wyrażeń biblijnych. Autorzy antyku chrześcijańskiego wzorowali się na praktyce stosowania prozopopei w tradycji klasycznej oraz biblijnej. Taka praktyka jest wskazywana jako wywodząca się ze szkół retorycznych epoki klasycznej i tam otrzymała podbudowę teoretyczną i techniczną ${ }^{69}$. Prozopopeję ćwiczono na wyższych stopniach edukacji o charakterze gramatycznym i retorycznym ${ }^{70}$. Zasady interpretacyjne prozopopei $z$ tradycji hellenistycznej przejął Orygenes. Jednak wcześniejsi pisarze chrześcijańscy, tacy jak Justyn, Hipolit i Klemens Aleksandryjski używali tego typu terminologii, mówiąc o Osobach Boskich i rozróżniając Je przy opisywaniu tajemnic Boga ${ }^{71}$.

Dzięki przykładom wziętym z Biblii, ten sposób interpretacji znalazł wszechstronne zastosowanie w kręgach chrześcijańskich. Orygenes wyraził przekonanie, że Duch Święty pozwala mówić różnym osobom w księgach biblijnych, niejako pojawiającym się na scenie historii zbawczej. Tak więc Duch Boży posługuje się narzędziem literackim, jakim jest prozopopeja, uwiarygodniając w sposób pośredni jego zastosowanie przez interpretatorów chrześcijańskich ${ }^{72}$. To przekonanie wielkiego egzegety aleksandryjskiego przyjęli późniejsi autorzy chrześcijańscy.

Zdobycze tego typu egzegezy były niekwestionowane, aż do tego stopnia że upatrywano w niej uzasadnienia użycia określenia prosōpon. W rzeczywistości jednak miało to znaczenie drugorzędne. Wskazywanie na osobę mówiącą odgrywało natomiast niepośrednią rolę w polemice chrześcijańskiej z Żydami

69 Zasady metodyczne opracował Eliusz Teon w traktacie Progymnasmata, napisanym prawdopodobnie pod koniec I wieku w Aleksandrii. Por. W. Siwakowska, Theon, w: Słownik pisarzy antycznych, red. A. Świderkówna, s. 457.

70 Wskazuje na to wyraźnie fragment Contra Celsum, w którym Aleksandryjczyk rozwodzi się nad konkretnym sposobem utworzenia prozopopei, aby później skrytykować swego adwersarza w tym właśnie duchu, dając jednocześnie świadectwo obeznania z literaturą na ten temat. Por. Contra Celsum VII, 36-37.

71 Por. B. Studer, Prosōpon, NDPAC, t. 3, kol. 4371.

72 Por. A. Villani, Origenes als Schriftsteller, s. 138-140. 
i monarchiami. Tego typu egzegeza pozwalała na podkreślenie rozróżnienia Osób Boskich, przede wszystkim wskazując na osoby Ojca i Syna ${ }^{73}$. Pod tym względem wydaje się ważny fragment Orygenesa, w którym on deklaruje:

„Kto chce uważnie czytać Pismo, ten powinien dokładać starań w tym względzie, ponieważ należy zwracać uwagę, przez kogo i w jakich okolicznościach są wypowiadane słowa, a byśmy wiedzieli, iż we W szystkich Świętych księgach wypowiedzi są przypisywane poszczególnym osobom zgodnie $\mathrm{z}$ charakterem tych, którzy je wygłaszają"74.

Prozopopeja była stosowana jako alternatywa lektury alegorycznej Eklezjastesa $^{75}$. Po prozopopeję sięgał nawet tak przekonany alegorysta jak Grzegorz z Nyssy. Starożytni egzegeci nie kryli trudności i zakłopotania wobec niektórych wersetów Eklezjastesa ${ }^{76}$. W tym kontekście znaczące jest zainteresowanie Koheletem ze strony Grzegorza Wielkiego. Były mu znane powody stosowania prozopopei w interpretacji tej księgi. Ten papież przenosi jednak na płaszczyznę kaznodziejstwa ten sposób odczytywania tekstu Koh. Na początku IV księgi Dialogów wyjaśnił znaczenie słowa „Eklezjastes”, rozumianego jako „kaznodzieja”. Oto uzasadnienie: „W kazaniu podawane są myśli, mające na celu uspokojenie hałasującego tłumu. A gdy wielu sądzi różnie, dowody, jakie podaje kaznodzieja, w ich umyśle jeden sąd wyrabiają. Dlatego ta księga kaznodziejską się nazywa, bo Salomon jakby za swoje przyjmuje zdanie hałaśliwej rzeszy i aby tym lepiej je poznać, niby od siebie wygłasza myśli, jakie niedoświadczony umysł mieć może. Przystosowuje się niejako do tylu różnych osób, w których imieniu się wypowiada"77.

Jest to swego rodzaju usprawiedliwienie masowego charakteru kaznodziejstwa, ale bez odrzucania skutecznych środków retorycznych. Celem było przekonanie słuchacza do głoszonych prawd i do ich przyjęcia ${ }^{78}$. Autor Koh

73 Zob. B. Studer, Prosōpon, kol. 4371-4372.

74 Orygenes, Commentarius in Joannem VI 8, 53.

75 S. Leanza, Sapienziali (libri), kol. 4735.

76 Istnienie sporów dotyczących Koh w niektórych kręgach żydowskich i chrześcijańskich potwierdza w IV w. Filastriusz z Brescii, por. Diversarum hereseon liber 134.

77 Dialogus IV, 4-5.

78 Papież Grzegorz Wielki pisząc do Narzesa, dostojnika dworu cesarskiego i swego przyjaciela, wspominał o niektórych figurach retorycznych. Ich stosowanie może sprawić, jak wytyka przyjacielowi, iż „małpę nazywasz lwem, widzę, że postępujecie podobnie jak ci, którzy nieraz nazywają "parszywe pieski» lampartami lub tygrysami”, Epistulae I, 6. 
„pewne opinie podaje jako wyraz cielesnych poglądów [...], [lub] jako prawdę duchową"79.

W ten i w podobny sposób autorzy starożytni otwierali innym oczy na określone sposoby i metody odczytywania tekstów biblijnych. Sugestie egzegetyczne wynikające z prozopopei były wykorzystywane w interpretacji Koh 9,4 nawet współcześnie ${ }^{80}$.

Wydaje się nawet, że biblijne porzekadło Koh 9,4 można połączyć z bajką Ezopową, w której psy pastwią się nad padliną lwa. Całą scenę obserwował lis, który zauważył, że gdyby lew żył, cała sprawa przybrałaby zupełnie inny obrót ${ }^{81}$. Ponadto ten obraz można zastosować do przysłowia pojawiającego się w bajkach Fedrusa („Wyrywać grzywę zdechłemu lwu”) ${ }^{82}$, gdy nawet osioł poniża zdychającego lwa ${ }^{83}$. Rzecz jasna materiał tego typu został wybrany i przefiltrowany przez autorów chrześcijańskich w bardzo precyzyjnych celach. Chodzi głównie o wskazania moralno-duchowe przykłady o charakterze retorycznym i kaznodziejskim (exempla).

\section{Szczegółowe refleksje nad Koh 9,4}

Spotykane na kartach Eklezjastesa zestawienia, tworzące antytetyczne pary pojedynczych wyrażeń, są w większości przypadków niejednoznaczne. Daje to czytelnikowi szerokie możliwości twórczej interpretacji tekstu. W przypadku Koh 9,4 wyjaśnienia starożytnych autorów nie kolidują z intencją tekstu, choć niektóre nie mogły być zapewne w intencji natchnionego autora. Przy zestawieniu poszczególnych interpretacji Ojców Kościoła, którzy komentowali ten werset, można nakreślić wspólne kierunki egzegetyczne w tradycji Kościoła.

\section{Dialogus IV, 8.}

80 Część badaczy uważa, że przytoczone przysłowie nie stanowi słów samego mędrca, ale jego oponentów w dyskusji. Por. J. Lemański, Negatywny obraz psa w Biblii, s. 67.

81 Por. L. Gibbs (transl.), Aesop's Fables, nr 231.

82 Por. Fedrus, Fabulae I, 21.

83 Nie brak współczesnych wersji tego przysłowia: „Lepiej żywy osioł niż nieżywy doktor"; zob. C. Stocchi, Dizionario della favola antica, s. 227. 
W tym względzie obfitszy materiał znajdujemy u autorów łacińskich, chociaż zdarza się często, że również ich komentarze nie dotrwały do naszych czasów ${ }^{84}$. W gronie autorów łacińskich to tajemniczy Ambrozjaster proponuje najwyraźniej już ugruntowaną egzegezę Koh 9,4. W jego zbiorze Quaestiones Veteris et Novi Testamenti przywołuje on ten fragment aż dwukrotnie. Quaestiones nie mają jednolitego charakteru, co też widać po interesujących nas fragmentach. Jeden z nich ma charakter typowo „akademicki”, a drugi zdradza znamiona homiletyczne ${ }^{85}$.

Ciekawym wątkiem u tego autora jest komentowanie Pawłowego tekstu $\mathrm{Rz}$ 8,19-22 w świetle $\mathrm{Koh}^{86}$. Ambrozjaster stosuje interpretację alegoryczną w przypadku Koh 9,4, jak się wydaje, nawet bez istotnego powodu. Dla niego wzmiankowane w tym tekście „ciemności” oznaczają „pogaństwo i niewiedzę" ${ }^{\text {". Swój }}$ wywód kontynuuje następująco:

„Natchniony autor pragnie nam wytłumaczyć, że jest więcej nadziei w człowieku przywiązanym do rzeczy materialnych niż w odstępcy. Na to wskazują następujące słowa: «Lepszy żywy pies, niż zdechły lew» (Koh 9,4). Powodem [tych słów] jest to, że lew to najsilniejsze ze wszystkich zwierząt, a religia chrześcijańska jest silniejsza niż wszystkie sekty. Jeśli więc odchodzimy od wiary w Boga, tracimy nadzieję na zbawienie i stajemy się gorsi od pogan. Dla pogan bowiem jest możliwe, że przyjmą wiarę i otrzymają prawo do zbawienia, które [z kolei] odrzucili odstępcy. Jeśli Boga nie poznają, nie uwierzą, to apostaci są w gorszym stanie. O wiele gorzej jest odrzucić zbawienie niż nigdy go nie posiadać. Sam

84 To przypadek komentarza autorstwa Wiktoryna z Petowium. U św. Hieronima, mimo krytycznego nastawienia do niektórych twierdzeń tego autora, daje się niejednokrotnie zauważyć przychylność do niektórych zasad jego egzegezy. Nie wiemy czy podobnie było z zaginionym komentarzem do Koh Panończyka oraz czy został on wykorzystany przez Strydończyka w jego rozważaniach na temat tej samej księgi biblijnej.

${ }^{85}$ W calym zbiorze Ambrozjastera można dostrzec te właśnie cechy. Por. M. Simonetti, Między dosłownością a alegorią, s. 249, przyp. 30.

86 „Marność to tyle, co zniszczalność. Albowiem wszystko, co rodzi się na świecie, jest słabe, przemijające i podlegające zniszczeniu i z tego względu marne. Marne bowiem jest to, co nie potrafi utrzymać swego stanu (cytaty z Koh 1,2 i Ps 38,6)... Czyż jedzenie i picie oraz troska o sprawy świata nie jest marnością? Jednakże nawet marność jest potrzebna... W porównaniu z bytami wiecznymi rzeczy zniszczalne są marne: choć same w sobie są dobre, jako że są konieczne”. In Epistolam Beati Pauli ad Rom. VIII, 20 A-B.

87 Por. M. Simonetti, Między dosłownością a alegorią, s. 250. 
[Pan] poucza, że pies przedstawia pogan. «Niedobrze jest zabrać chleb dzieciom, a rzucić psom» (Mt 15,26)"88.

W innym miejscu Ambrozjaster pomija szczegółowe kwestie oparte na trudnościach przedstawionych przez tekst Koh 9,4. Stwierdza po prostu: „Zdechłym lwem jest chrześcijanin odstępca. Tak, jak długo trwa w wierze, jest jak lew, a gdy ją straci? Jest jak zdechły lew. Psem jest poganin, który, jak ufamy, przyjmie wiarę. Tę nadzieję mamy póki on żyje. W przeciwnym razie i nadzieja ginie"89.

Mimo preferencji dla egzegezy dosłownej, Ambrozjaster posługuje się alegoryzmem. Czyni to w sposób naturalny, chociaż raczej rzadko. W przypadku analizowanego wersetu i jego kontekstu chodzi o metodologię w pełni akceptowaną.

Eucheriusz z Lyonu ujmuje skrótowo wyjaśnienie Koh 9,4. Wśród świadectw biblijnych przypomina, że „w innej części Księgi Koheleta [napisano]: «Żywy pies jest lepszy niż martwy lew» (Koh 9,4). [Niektórzy] uważają, że lew to diabeł, pies zaś to prawdziwy poganin lub człowiek przyjmujący grzesznika, ponieważ jeden może dojść do wiary lub pokuty, drugi natomiast nie"90.

Widać tutaj, obecne także w chrześcijaństwie, negatywne postrzeganie lwa ${ }^{91}$. Ponadto obok klasycznego zestawienia pies - poganin, dochodzi „przyjmownaie grzesznika” czyli zgoda na zło i współuczestnictwo w nim. Odnośnie do poganina są większe nadzieje, niż do tego, który pozostaje uwikłany w zło.

Od tonu moralizatorskiego nie odbiega apoftegmat wykorzystujący Koh 9,4. Ten werset znajdujemy w ustach abby Pojmena. Pewnego dnia jeden z mnichów zapytał go: „Mój ojcze, czymże jest «żywy pies i martwy lew?». Odpowiedział mu [abba Pojmen]: «Żywy pies» to jest brat, który ma złe imię, a bracia, którzy go widzą, mówią o nim: jest zły; dzieło jednak jego u Boga jest dobre i bardzo piękne. «Martwy zaś lew» to jest brat, który ma dobre imię u wszystkich braci, ale czyny jego między nim a Bogiem, są martwe i bardzo marne" ${ }^{\text {"2 }}$. Na tym skromnym przykładzie widać, że Pismo Święte było dla mnichów punktem odniesienia, skąd czerpali inspirację duchową i wykładnię postępowania. Stąd także specyficzną cechą interpretacji biblijnej, która pojawiła się w kręgach ascetycz-

\footnotetext{
88 Quaestio XXXIX.

89 Quaestio XIX. Swoje rozważanie autor kończy fragmentem Mt 15,26.

90 Eucheriusz z Lyonu, Formulae V (De animantibus).

91 Przed szatanem, krążącym jak lew i szukającym, kogo pożreć, przestrzega 1 P 5,8.

92 Apophthegmata Patrum [kolekcja monastyczna] 13,10.
} 
nych, jest przede wszystkim pragmatyzm ${ }^{93}$. Natchnione teksty nie potrzebowały uczonych dysput, lecz woli, by wcielać je w życie.

Przywołany apoftegmat nie to jedyny przypadek użycia tego typu porównań w literaturze monastycznej ${ }^{94}$. Należy brać pod uwagę, że tekst Koh był cytowany niejednokrotnie w źródłach monastycznych. W kręgach ascetycznych znano również komentarze do tej księgi i powstawały nowe, jak te autorstwa Ewagriusza z Pontu i Nila z Ancyry ${ }^{95}$.

Pochodzący z Palestyny Epifaniusz całą swoją wiedzę i energię wykorzystywał w walce $\mathrm{z}$ błędami doktrynalnymi. W polemicznym dziele Ancoratus przytacza antologię tekstów o dobroci Chrystusa ${ }^{96}$, odnoszącej się zarówno do Jego bóstwa jak i człowieczeństwa. Jest to typowa metoda tworzenia świadectw biblijnych na określony temat (tzw. Testimonia) ${ }^{97}$. Poszczególne wersety lub perykopy grupowano według tematyki teologicznej z myślą o głównych wątkach katechezy. Każda perykopa stawała się nierozłączna ze swoim „kluczem”, który otwierał jej sens i tajemnicę ${ }^{98}$.W sporach i polemikach wczesnochrześcijańscy pisarze korzystali obficie z tych antologii tekstów biblijnych. Dla Epifaniusza Biblia to „źródło doktryny. Jej nauki jednak są liczne i różnorodne, tak jak różne są znaczenia określenia "dobry»"99. Przyszły biskup Salaminy zasypuje dosłownie czytelników fragmentami Pisma Świętego odnoszącymi się do kluczowego

93 Mimo tego faktu częstotliwość cytowania Biblii np. w Apoftegmatach jest raczej ograniczona. Warto jednak zaznaczyć, że z pewną intensywnością pojawiały się teksty z ksiąg mądrościowych, chociaż Koh stanowił wyjątek. B. De Margerie, Introduzione alla storia dell'esegesi, t. 1, s. 150 .

94 W źródłach etiopskich zachowała się wizja św. Pachomiusza o dziesięciu zastępach mnichów: złych i dobrych. Niegodziwi mnisi zostają tam porównani do psów, ponieważ „żyją we wspólnocie, ale mają własne dobra”. Powód jest następujący: „Pies nie pozostawia tego, co znalazł [...]. Nie ma rzeczy, od której by się nie powstrzymał", III Regula Pachomii, Apoftegmaty, t. 3, s. 66.

95 Por. M. Starowieyski, Księga Eklezjastesa, s. 272, przyp. 5.

96 Epifaniusz snuje swoją refleksję na kanwie Łk 18,19 i Mk 10,18.

97 Przykład tej formy literackiej stanowią Testimonia ad Quirinum Cypriana z Kartaginy. Ta antologia testów biblijnych powstała w latach 248-250.

98 Przez długi okres czasu egzegeza chrześcijańska Starego i Nowego Testamentu opierała się na tego typu zbiorach.

99 Ancoratus 18, 4. 
słowa „dobry”, ale cytowanymi niemal bez komentarzy. W całym zbiorze można znaleźć Koh 9,4 ${ }^{100}$.

W opinii Hieronima dopiero na fundamencie analizy literackiej i dosłownej odnajduje się sens duchowy. Łaciński komentator Eklezjastesa korzystał ze zdobyczy wcześniejszej tradycji interpretacyjnej. Nie jest wykluczone, że w pewnej części była to tradycja judaistyczna. Refleksje autora Wulgaty mają więc charakter bardziej literacko-erudycyjny niż ascetyczno-moralny. W przypadku komentarza do Koh ma się do czynienia z cennym kompendium hermeneutyki ówczesnego czasu. Hieronim przywoływał tekst Koheleta także poza kontekstem systematycznego komentarza, przy okazji polemik.

Zdaniem św. Hieronima Koh 9,4 to dopełnienie wcześniejszych refleksji tej księgi o końcu wszystkiego wraz ze śmiercią. „Póki człowiek żyje, może stać się sprawiedliwym, po śmierci zaś nie ma już żadnej sposobności do pełnienia dobrych uczynków. Zatem żywy grzesznik może być lepszy od sprawiedliwego zmarłego, jeśli tylko zechce przyjąć jego cnoty. Podobnie byle jaki biedak, choćby nie wiem jak nędzny, jest z pewnością lepszy od zmarłego, który za życia chełpił się złem, władzą i zuchwałością. Dlaczego? Ponieważ lęk przed śmiercią może skłaniać żyjących do dobrych czynów, natomiast zmarli nie mogą nic dodać do tego, co raz zabrali ze sobą, odchodząc z tego świata... Wszystko spowija niepamięć ${ }^{101}$ [...]. [Wszystko] kończy się wraz z nadejściem śmierci i nie mogą już uczynić nic sprawiedliwego, ani zgrzeszyć; przymnożyć cnót, ani przywar"102.

W komentarzu do Koh 9 Strydończyk wyraźnie sugerował, że Salomon wprowadzał opinie różnych autorów, na sposób „retorów, [pogańskich] poetów i [...] filozofów”. To właśnie prozopopeja pozwala mu nie odrywać się od sensu dosłownego i akcentować znaczenie moralne. Przywołuje także odmienne i kontrowersyjne opinie. „Niektórzy sprzeciwiają się takiej [tj. wcześniejszej] interpretacji, twierdząc, że i po śmierci możemy wzrastać bądź maleć”. Według ich opinii, „po odejściu z tego świata jesteśmy w stanie, jako stworzenia rozumne, grzeszyć i zyskiwać zasługę"103.

100 Inne wersety to: Koh 4,13; 7,2.8; 9,9; 18,17. Ponadto 1 Sm 2,26; 9,2; Pwt 28,12, Przywołane zostały dwa teksty ewangeliczne: Mt 7,11 i Mk 10,17. Zob. Ancoratus 18, 4.

101 To zdanie poparte jest słowami Ps 31,13.

102 Commentarius in Ecclesiasten IX, 4b-6.

103 Ibidem. 
Hieronim przytacza następnie „interpretację Hebrajczyka” ${ }^{104}$, który „inaczej tłumaczy werset: «Żywy pies lepszy jest od martwego lwa». Wśród swoich w ten sposób go wyjaśnia: bardziej pożyteczny jest ktoś niewykształcony, lecz jeszcze żywy i udzielający nauk, niż doskonały mistrz, który już umarł. Na przykład «psem» może być pierwszy lepszy spośród wielu nauczycieli, «lwem» zaś Mojżesz lub inny z proroków" ${ }^{\prime 05}$. Zwrócono uwagę, że ten wątek obecny jest w tradycji rabinistycznej ${ }^{106}$. Strydończyk odnosi się z dezaprobatą do tego wyjaśnienia i przywołuje Mt $15,26^{107}$. Z pewnością ironia wyrażona w przekazie midraszowym wydawała się Strydończykowi zbyt daleko posunięta. Zdawał sobie sprawę, że nie można pozbawiać tekstu sensu, którego on nabrał i odczytywać go abstrahując od kontekstu chrześcijańskiej tradycji egzegetycznej ${ }^{108}$.

Swój wywód autor Wulgaty uzupełnił jeszcze proroctwem Balaama: „ «Oto naród powstaje jak szczenię lwa, podnosi się jak lew» $\left(\right.$ Lb 24,9) ${ }^{109}$. Zatem żywym psem jesteśmy my, którzy pochodzimy z narodów pogańskich, martwym zaś lwem lud żydowski, który Pan opuścił ${ }^{110}$; i lepszy jest w oczach Pana ten żywy pies niż tamten martwy lew. My, żywi, poznajemy Ojca i Syna, i Ducha Świętego, oni zaś, umarli, nie znają niczego, nie spodziewają się obietnicy ani łaski, lecz pamięć o nich zanikła. Nie pamiętali o tym, co wiedzieć powinni, a i Bóg ze swojej strony nie pamięta o nich. Przepadła miłość, którą niegdyś kochali Boga"111.

104 Odnośnie do tej kwestii por. M. Simonetti, Między dosłownością a alegorią, s. 331, przyp. 320. W niektórych przypadkach sugestie anonimowego „hebrajskiego nauczyciela” (magister hebraeus) nie były brane pod uwagę przez Hieronima także w odniesieniu do wersji tłumaczenia.

105 Commentarius in Ecclesiasten IX, 4b-6.

106 Por. Midrasz Kohelet Rabbah 9, 4, 1. Cyt.wg K. Bardski (tłum.), Św. Hieronim, Komentarz do Księgi Eklezjastesa, s. 166.

107 W podobny, polemiczny sposób Hieronim wielokrotnie ukazywał metodę lektury świętych tekstów, tłumaczonych na „modłę cielesną” (carnaliter).

108 Hieronim nie zamykał się bynajmniej w schemacie dosłowności. Był on przekonany, że błędem żydowskiej dosłowności jest odrzucenie możliwości przejścia do sensu duchowego tekstu biblijnego, a tym samym jego niezwykłego bogactwa.

109 Proroctwo Balaama było często przywoływane w literaturze wczesnochrześcijańskiej. O popularności postaci pogańskiego proroka świadczy bogata ikonografia, por. G. Santagata, Balaam (iconografia), NDPAC, t. 1, kol. 687-688.

110 Wg słów Zbawiciela: „Królestwo Boże będzie wam zabrane, a dane narodowi, który wyda jego owoce" (Mt 21,43)", por. Hieronim, In Isaiam XIII, 48, 1.

111 Commentarius in Ecclesiasten IX, 4b-6. 
Hieronim interpretuje Koh 9,4 według klucza zastąpienia narodu żydowskiego przez wspólnotę chrześcijan. W porządku łaski zostało zastąpione dawne Prawo. W celach katechetycznych Ojcowie Kościoła często syntetyzowali dzieje biblijnego Izraela i zestawiali je z dziełem Zbawiciela i Kościołem. W tym konkretnym przypadku służyła temu antyteza: żywy pies - nieżywy lew.

Koh 9,4 zostaje przypomniany w traktacie polemicznym, w którym Hieronim stara się zdyskredytować na wszelkie sposoby jednego ze swoich adwersarzy o imieniu Wigilancjusz. Skutecznym zabiegiem autora Wulgaty było używanie satyry, między innymi notoryczne przekręcanie imienia heretyka $z$ Wigilancjusza na Dormitancjusz. Miało to umocnić przekonanie, że właśnie owo szydercze przezwisko (tj. „Śpiący”), a nie imię, oddaje prawdę o osobie heretyka. W takim właśnie kontekście pojawia się cytat Koh 9, 4.

Hieronim stawia pytanie: „Czy lepszy będzie Wigilancjusz, «żyjący pies», niż ten [Paweł], «umarły lew»? Przytoczyłbym słusznie to [przysłowie] z Księgi Eklezjastesa, gdybym uznał, że Paweł przez jakiś moment był umarły duchem. Ostatecznie jednak świętych nie nazywa się «umarłymi», lecz «śpiącymi». Dlatego o Łazarzu, który miał być wskrzeszony, twierdzi się, że spał. Apostoł zabrania Tesaloniczanom martwić się o śpiących. A ty [tymczasem] śpisz, czuwając, a piszesz śpiąc" 112 .

Swoiste curiosum stanowi list św. Kolumbana do papieża Grzegorza Wielkie$\mathrm{go}^{113}$. Porusza w nim problem dotyczący obchodzenia Paschy. W ujęciu Kolumbana niewłaściwa data Wielkanocy to celebracja tego święta „w ciemnościach”. W tak ważnej sprawie nie należy ufać „jedynie pokorze czy powadze, one bowiem często dają się zwieść; może lepszy w tej niejasnej kwestii jest «żywy pies niż martwy lew». Albowiem, ten, kto żyje i cieszy się szacunkiem, może poprawić to, co przez innego, chociaż dostojnego, poprawione nie zostało"114. Zwraca uwagę gra słów pomiędzy imieniem papieża (Leon), na którego autorytet się powoływano, a wzmianką o lwie (leo).

Jak wiadomo, Koh znajdował się w kręgu zainteresowania środowisk monastycznych także w okresie późniejszym. Świadczą o tym nie tylko Apoftegmaty

\section{Adversus Vigilantium 6.}

113 List z 600 r. Jako jedyny przykład egzegezy patrystycznej Koh 9,4 ten fragment jest obecny w: M. Przyszychowska (wyd.), Ojcowie Kościoła komentują Biblię, t. 8, s. 256.

114 Kolumban, Epistula 1, 4. Również Nil z Ancyry, zajmował się księgą Eklezjastesa w swoich listach. 
zredagowane $\mathrm{w}$ językach orientalnych ${ }^{115}$, ale również późny komentarz Grzegorza z Agrigentum (przełom VI i VII w.) ${ }^{116}$, który był prawdopodobnie skierowany właśnie do tego środowiska i nawiązywał do wcześniejszych dzieł autorów greckich o tym charakterze. Zawiera on syntezę tradycji antiocheńskiej i aleksandryjskiej, przy harmonijnym wykorzystaniu zdobyczy egzegezy poprzedników Przeważają w nim zachęty o charakterze moralnym i nawiązania do zasad etycznych, ale często odbiega od tego schematu ${ }^{117}$.

Kontrowersyjne tezy obecne w księdze Eklezjastesa Grzegorz uważa za „fałszywe opinie o Najwyższym Bogu". Wskazuje na dwie kategorie ludzi, gdyż obok tych, którzy „prowadzą dobre życie i miłują Boga”, są i ci „prowadzący życie godne nagany i bezbożne”. To oni wprowadzają „niegodziwe opinie o życiu po śmierci" "118. Grzegorz uważał, że te sądy były inspirowane przez demony. To stały element literackiej tradycji monastycznej, podkreślającej demoniczny charakter wszystkich złych myśli ${ }^{119}$.

Porównanie do psa wiąże się z „nędzą, biedą i ubóstwem”. Dla człowieka w tym stanie istnieje możliwość poprawy. Lew ucieleśnia władzę i moc, ale w refleksji Grzegorza przedstawia „pychę i zarozumiałość, [to ktoś] chlubiący się purpurą diademem, klejnotami i perłami” ${ }^{120}$. To bezpośredni opis wskazujący na antropomorficzne potraktowanie cech charakterystycznych dla psa i lwa. Tak więc ten, kto „kto umarł w bezbożności, w swoich nieprawidłowościach i występach, nawet jeśli wcześniej cieszył się bogactwem i sławą [...], upada niżej niż najnędzniejszy" ${ }^{\prime 21}$. W przyszłym świecie, ten kto był porównany do psa, a wychodzi z nędzy moralnej na wyżyny cnoty, zostaje wyróżniony i wywyższo$n y^{122}$. To motywacja do wyzbycia się czysto ziemskiej optyki i starania się o to, co pomaga dojść do zbawienia.

115 Zob. M. Starowieyski, Ksiegga Eklezjastesa, s. 270, przyp. 42; 281-282.

116 Zob. In Ecclesiasten libri X, por. PG 98,741-1181.

117 Por. M. Starowieyski, Księga Eklezjastesa, s. 281.

118 In Ecclesiasten VIII, 5.

119 Ewagriusz z Pontu używał zamiennie określeń „zła myśl” i „demon”.

120 In Ecclesiasten VIII, 5.

121 Ibidem.

122 Por. ibidem. 
Niektóre fragmenty Koh, mimo interpretacji moralno-duchowej, budziły nadal dyskusje, stąd nie zniknęła konieczność ich wyjaśnienia, o czym świadczą komentarze epoki średniowiecznej ${ }^{123}$.

\section{Zakończenie}

Odnośnie do egzegezy Księgi Eklezjastesa mamy do dyspozycji różnorodny materiał, aby starać się prześledzić jej szlaki interpretacyjne. Odpowiedzi dotyczącej kierunków należy poszukać nie tylko w literaturze egzegetycznej, ale również w zbiorach pouczeń ascetycznych, homiletyce i listach. Rodzi się pytanie, czy egzegeza tej księgi była przewidywalna? Z pewnością tak było pod wieloma względami, bo przecież Ojcowie Kościoła trzymali się wspólnych linii interpretacyjnych i stosowali wypróbowane metody egzegetyczne. Miało to miejsce mimo pewnej fluktuacji zainteresowania tą księgą w zależności od kręgu językowego. Gdy jednak spojrzy się na szczegóły i interpretację pojedynczych wersetów, widać różnorodność i pewną swobodę stosowania narzędzi egzegetycznych. W przypadku Koh 9,4 wartością dodaną jest stosowanie tego wersetu jako przysłowia. Mimo, że materiał nie okazał się zbyt obfity, to jednak pojawiły się znaczące przykłady lektury tego fragmentu. To właśnie na nie starano się zwrócić uwagę w przedstawionym opracowaniu.

\section{Bibliografia}

\section{Źródła}

Aesop's Fables, transl. L. Gibbs, Oxford 2002.

Ambrosiaster, Ambrosiastri qui dicitur commentarius in epistulas Paulinas, ed. H. I. Vogels,

Corpus Scriptorum Ecclesiasticorum Latinorum [= CSEL] 81, pars I, Vindobonae 1966.

Ambrosiaster, Quaestiones, w: Pseudo-Augustini Quaestiones Veteris et Novi Testamenti CXXVII, ed. A. Souter, CSEL 50, Wien 1960.

Ambrosius, De benedictionibus patriarcharum, Patrologia Latina [= PL] 14, kol. 673-690.

123 Por. lista komentarzy poświęconych Koh wg. M. Starowieyski, Księga Eklezjastesa, s. 298-303. 
Ambrosius, Exameron, ed. G. Banterle, Opera Omnia di Sant'Ambrogio 1, Milano 1979, tłum. W. Szołdrski, Starochrześcijańskich Pisarzy [= PSP] 4, Warszawa 1969.

Apoftegmaty Ojców Pustyni, t. 3: Zbiory etiopskie (wybór), mniejsze zbiory greckie, zbiory łacińskie, S. Kur i in. (tłum.), Źródła Monastyczne [= ŹM] 56, Kraków 2011.

Augustinus Hipponensis, Enarrationes in Psalmos, ed. V. Tarulli, T. Mariucci, F. Monteverde, Nuova Biblioteca Agostiniana 27-28, Roma 1976-1977, tłum. J. Sulowski, Święty Augustyn, Objaśnienie Psalmów, z. 1-2, Pisma Starochrześcijańskich Pisarzy [= PSP 37], 42, Warszawa 1986.

Augustinus, Speculum. Liber de divinis scripturis, ed. F. Weihrich, CSEL 12, Wien 1887.

Basilius Magnus, In Hexaemeron, ed. S. Giet, Sources Chrétiennes [= SCh] 26 bis, Paris $1968^{2}$.

Didymus Caecus, Kommentar zum Ecclesiastes (Toura Papyrus), ed. M. Groenwald, Papirologische Texte und Abhandlungen 22, Bonn 1977.

Epiphanius, Ancoratus, ed. K. Holl, Die griechischen christlichen Schriftsteller der ersten drei Jahrhunderte 25, Leipzig 1915.

Eucherius Lugdunensis, Formulae spiritualis intelligentiae, PL 50, 727 A-772 D.

Fedrus, Bajki Ezopowe, przeł. i oprac. P. Gruszka, Gdańsk 1999.

Filastrius Brixiensis, Diversarum hereseon liber, ed. F. Heylen - G. Banterle, Scriptores circa Ambrosium, t. 2, Milano - Roma 1991.

Gregorius Agrigentinus, In Ecclesiasten libri X, Patrologia Graeca [= PG] 98, kol. 741-1181. Gregorius Magnus, Dialogorum libri IV, ed. A. de Vogüe, SCh 251, 260, 265, Paris 19781980, tłum. W. Szołdrski, Św. Grzegorz Wielki, Dialogi, PSP 2, Warszawa 1969.

Gregorius Magnus, Registrum epistularum, Ed. D. Norberg, Corpus Christianorum. Series Latina [= CCL] 140, 140A, Turnholti 1982, tłum. J. Czuj, Św. Grzegorz Wielki, Listy, t. I-IV, Warszawa 1954-1955.

Hieronymus, Adversus Vigilantium, ed. J.-L. Feiertag, CCL 79 C, Turnhout 2005, tłum. G. Rurański, Św. Hieronim ze Strydonu, Pisma polemiczne. Przeciw Helwidiuszowi. Przeciw Jowinianowi. Przeciw Wigilancjuszowi, ŹM 67, Kraków 2013.

Hieronymus, Commentarius in Ecclesiasten, PL 23, kol. 1009-1116, tłum. K. Bardski, Św. Hieronim, Komentarz do Księgi Eklezjastesa, Biblioteka Ojców Kościoła 5, Kraków 1995. Hilarius Pictaviensis, Commentarius in Matthaeum, ed. J. Doignon, SCh 254; 258, Paris 1978-1979, tłum. E. Stanula, Św. Hilary z Poitiers, Komentarz do Ewangelii św. Mateusza, PSP 63, Warszawa 2002.

Hippolytus, Interpretatio Cantici Canticorum, ed. G. Garitte, Corpus Scriptorum Christianorum Orientalium 263-264, s. 32-70, 23-53, Paris 1965.

Joannes Chrysostomus, Homiliae in Matthaeum 41-90, PG 58, kol. 647-662, tłum. A. Baron, Św. Jan Chryzostom, Homilie na Ewangelię według św. Mateusza, cz. 2: Homilie 41-90, Źródła Myśli Teologicznej [= ŹMT] 23, Kraków 2001, s. 321-343.

Joannes Chrysostomus, In Ecclesiasten, ed. S. Leanza, Corpus Christianorum. Series Graeca 4, Turnhout 1978, s. 67-97. 
Origenes, Commentarium in Canticum canticorum, éd. L. Brésard - H. Crouzel - M. Borret, SCh 375-376, Paris 1991-1992, tłum. S. Kalinkowski, w: Orygenes, Komentarz do „Pieśni nad Pieśniami”. Homilie o „Pieśni nad Pieśniami”, Kraków 1994.

Origenes, Commentarius in Joannem, ed. C. Blanc, SCh 120, 157, 222, 290, Paris 1966;1970; 1975; 1982, SCh 385, Paris 1992, tłum. S. Kalinkowski, Orygenes, Komentarz do Ewangelii według św. Jana, ŹMT 27, Kraków 2003, 25-562.

Origenes, Contra Celsum, ed. M. Borret, SCh 132, Paris 1967, SCh 136, 147, 150, Paris 1968-1969, tłum. S. Kalinkowski, Orygenes, Przeciw Celsusowi, Warszawa 1986.

Origenes, De principiis, ed. H. Crouzel - M. Simonetti, SCh 252-253; 268-269; 312, Paris 1978-1980; 1984, tłum. S. Kalinkowski, W. Stanula, oprac. W. Myszor, Orygenes. O zasadach, PSP 23, Warszawa 1979.

Przyszychowska M. (wyd.), Ojcowie Kościoła komentują Biblię. Stary Testament, t. 8: Księga Przysłów, Księga Koheleta, Pieśń nad Pieśniami, Ząbki k. Warszawy 2015.

Sancti Columbani Opera, ed. G. S.M. Walker, Scriptores Latini Hiberniae, t. II, Dublin 1957, tłum. E. Zakrzewska-Gębka Św. Kolumban, Pisma, Jonasz z Bobbio, Żywot Kolumbana, PSP 60, Warszawa 1995.

Sancti Epiphanii episcopi Interpretatio evangeliorum, ed. A. Erikson, Lund 1939.

Wright J. R., Ancient Christian Commentary on Scripture, t. 9: Proverbs, Ecclesiastes, Song of Solomon, Illinois 2005.

\section{Opracowania}

Bardski K., Poemat o czasie właściwym (Koh 3,1-8) w starożytnej interpretacji judaistycznej i chrześcijańskiej, w: Jak śmierć potężna jest miłość (Pnp 8,6). Księga pamiątkowa ku czci Księdza Profesora Juliana Warzechy SAC (1944-2009), red. W. Chrostowski, Ząbki 2009, s. 25-32.

De Margerie B., Introduzione alla storia dell'esegesi. Padri greci e orientali, t. 1, Roma 1983.

Forstner D., Świat symboliki chrześcijańskiej, tłum. W. Zakrzewska, Warszawa 1990.

Grillo J., Is Patristic Exegesis Good for Biblical Scholarship? Jerome and Gregory of Nyssa on Qohelet, w: J. Jarick (ed.), Perspectives on Israelite Wisdom. Proceedings of the Oxford Old Testament Seminar (The Library of Hebrew Bible/Old Testament Studies), London 2006, s. 232-253.

Holm-Nielsen S., On the Interpretation of Qoheleth in Early Christianity, Vetus Testamentum 24 (1974), s. 168-177.

Kobielus S., Bestiarium chrześcijańskie. Zwierzęta w symbolice i interpretacji. Starożytność i średniowiecze, Warszawa 2002.

Leanza S., I condizionamenti dell'esegesi patristica. Un caso sintomatico: l'interpretazione di Qohelet, Ricerche Storico Bibliche 2 (1990), s. 25-49. 
Leanza S., L'esegesi patristica di Qohelet da Melitone di Sardi alle compilazioni catenarie, w: Letture cristiane dei Libri Sapienziali. XX Incontro di studiosi dell'antichità cristiana 9-11 maggio 1991, Studia Ephemeridis „Augustianum” 37, Roma 1992, s. 237-250.

Lemański J., Negatywny obraz psa w Biblii. Przyczyny i konsekwencje, Colloquia Theologica Ottoniana 1 (2011), s. 67. 51-96

Masłowska D., Masłowski W., Przysłowia polskie i obce od A do Z, Warszawa 2003.

Müldner-Nieckowski P., Wielki słownik frazeologiczny języka polskiego, Warszawa 2003.

Nuovo dizionario patristico e di antichitá cristiane [= NDPAC], ed. A. Di Berardino, t. 1-3, Genova - Milano 2006-2008.

Pastoureau M., Średniowieczna gra symboli (Horyzonty Cywilizacji), przeł. H. Igalson-Tygielska, Warszawa 2006.

Penna A., Principi e carattere dell'esegesi di S. Girolamo, Roma 1950.

Przyszychowska M. (wyd.), Ojcowie Kościoła komentują Biblię. Stary Testament, t. 8: Ksiegga Przysłów, Księga Koheleta, Pieśń nad Pieśniami, Ząbki k. Warszawy 2015.

Purc-Stępniak B., Lwy zła - lwy cnoty. Ikonograficzne aspekty obrazowania motywu lwa w sztuce nowożytnej, w: Lwy w heraldyce i w sztuce europejskiej. Międzynarodowa konferencja historyczna, zorganizowana przez Uniwersytet Gdański i Fundacje Współpracy Wspólnota Gdańska - 23 października 2008, red. T. Maćkowski, Gdańsk 2008, s. 5-19.

Schattner-Rieser U., Le „Chien” dans la tradition juive des littératures bibliques et para - et postbiblique (Ahiqar, écrits de Qumrân, pseudépigraphes et littérature rabbinique), Res Antiquae 6 (2009), s. 293-304.

Simonetti M., Między dosłownością a alegorią. Przyczynek do dziejów egzegezy patrystycznej, tłum. T. Skibiński, Kraków 2000.

Słownik pisarzy antycznych, red. A. Świderkówna, Warszawa 1990.

Starowieyski M., Księga Eklezjastesa w starożytności chrześcijańskiej, Warszawskie Studia Teologiczne (numer specjalny 2017), s. 270-305 (przedruk z Vox Patrum 10/19 [1990], s 771-806).

Stocchi C., Dizionario della favola antica, Milano 2012.

Szram M., „Wszystko ma swój czas”. Patrystyczna egzegeza Księgi Eklezjastesa 3,1-8, Verbum Vitae 35 (2019), s. 345-372.

Villani A., Origenes als Schriftsteller: Ein Beitrag zu seiner Verwendung von Prosopopoiie, mit einigen Beobachtungen über die prosopologische Exegese, Adamantius 14 (2008), s. 130-150 .

von Bardenhewer O., Geschichte der altkirchlichen Literatur, t. 5: Die letzte Periode der altkirchlichen Literatur mit Einschluß des ältesten armenischen Schrifttums, Freiburg im Breisgau 1932.

Wright J. R., Ancient Christian Commentary on Scripture, t. 9: Proverbs, Ecclesiastes, Song of Solomon, Illinois 2005. 